Proc. Indian Acad. Sci. (Earth Planet. Sci.), Vol. 95, No. 3, November 1986, pp. 351-361.

(C) Printed in India.

\title{
Palaeo-tectonic environment of the Precambrian basaltic mafic dykes on the application of chemical discriminants
}

\author{
T RAMAMOHANA RAO, B V SATYANARAYANA RAJU and \\ M V RAMA RAJU \\ Department of Geology, Andhra University, Waltair 530003 , India \\ MS received 29 September 1984; revised 31 March 1986
}

\begin{abstract}
Dykes of Chitaldurg and Newer Dolerite I are OFB and represent early attempts to rift and to generate oceanic crust. Shimoga dykes are $\mathrm{CAB}$ and belong to orogenic phase. Guntur dykes and Ananthapur-Chittoor dykes are OIB and these are related to 'hot spot'. Newer Dolerite II is CONB and belongs to healing and filling of fractured crust. The Cuddapah dykes are transitional to all magma types and these represent a compound event of rifting and filling of fractured continental crust.
\end{abstract}

Keywords. Palaeo-tectonic environment; mafic dykes; chemical discriminant.

\section{Introduction}

The advent of plate tectonics paradigm has stimulated the earth scientists to classify the basaltic magma types in terms of tectonic setting of the Phanerozoic volcanics. The principal tectonic settings and the related basaltic magma types are as follows: (1) Converging plate margin as in the subduction zone of island arc basalts (IAB) characterized by early low potassium tholeiite (LKT) followed mainly by calc-alkaline basalt (CAB) and minor shoshonite (SHO), (2) diverging plate margin as in the mid-oceanic ridge basalt (MORB) characterized by low potassium tholeiitic basalt enriched in $\mathrm{Cr}, \mathrm{Ni}$ and impoverished in lithophile elements, (3) within plate ocean island basalts (OIB), characterized by alkali basalt and tholeiitic basalt, (4) within plate continental basalt (CONB), characterised by tholeiitic basalt and alkali basalt. The OIB and CONB are together described as within plate basalts (WPB). The marginal basin basalts (MBB), though relatively impoverished in $\mathrm{Ni}, \mathrm{Cr}$ and relatively enriched in lithophile elements are considered similar to mid-oceanic ridge basalts (MORB), on the basis of major element composition and these together are described as the ocean floor basalts (OFB). The orogenic basalts (ORNB) are calc-alkaline basalts and these are considered similar to and equated to island arc basalts (IAB).

The observed chemical variations of the basaltic magma of different tectonic environments, whether these are due to dynamical partial melting of a homogeneous mantle source or due to heterogeneity of the mantle, is one of the most actively and lively debated topics in the earth sciences (Hanson 1977; Langmuir et al 1977, 1980; Hawkesworth et al 1977; O'Nions et al 1978, 1979, 1981; Sun 1980; Tarney et al 1980; Allégre et al 1980; Dupre et al 1981; Allégre 1982; Stern 1982; Morris and Hart 1983; Gill 1984; Wilkinson 1985; Hamelin et al 1986). A large number of studies from U-Pb, $\mathrm{Sm}-\mathrm{Nd}, \mathrm{Rb}-\mathrm{Sr}$ systematics, light REE and 
LILE have brought out that the convective mantle is chemically heterogeneous. The current ideas on the basaltic magma are that the source of MORB is the Low Velocity Zone (LVZ) of the mantle which is severely depleted in highly incompatible elements $\mathrm{Cs}, \mathrm{Ba}, \mathrm{Rb}, \mathrm{U}, \mathrm{Th}, \mathrm{K}, \mathrm{La}$ and $\mathrm{Nb}$ and the source of OIB is the Lower Mantle (possibly generated through plume-hot spot) which is relatively undepleted in the incompatible elements compared to the whole Mantle while the source of IAT is in the Uppermost Mantle separated from the source of MORB by the subducted lithosphere of oceanic basalt and sediment and is not as depleted as MORB in the incompatible elements. The ratios and the relative variations of $\mathrm{Sr}_{87} / \mathrm{Sr}_{86},{ }^{207} \mathrm{~Pb} / \mathrm{Pb}_{204},{ }^{206} \mathrm{~Pb} / \mathrm{Pb}_{204},{ }^{143} \mathrm{Nd} /{ }^{144} \mathrm{Nd}$ have been extensively used; the depleted mantle is generally richer in the ratio of ${ }^{143} \mathrm{Nd} /{ }^{144} \mathrm{Nd}$ and poorer in $\mathrm{Sr}_{87} / \mathrm{Sr}_{86}$ while the converse is the case with the undepleted mantle.

Certain groups of elements which are immobile or less mobile in the secondary processes and whose relative concentrations reflect the compositional differences among the magma types erupted at different tectonic environments have been proposed as chemical discriminants by way of diagrams with demarcated fields of environments (Pearce and Cann 1973; Pearce et al 1975, 1977; Pearce and Norry 1979; Floyd and Winchester 1975; Pearce 1976, 1982; Wood et al 1979; Wood 1980; Thompson et al 1980; Gill 1984). The ratios of some elemental pairs, Th/Hf, $\mathrm{Zr} / \mathrm{Nb}$, $\mathrm{La} / \mathrm{Nb}, \mathrm{Ba} / \mathrm{La}, \mathrm{Sr} / \mathrm{Nd}$ have also been found helpful as discriminants.

The application of chemical discriminants has been extended to Precambrian metavolcanics. The Precambrian mafic dykes (and other continental basalts) show certain features which merit a closer examination of their palaeo-tectonic environments from the application of chemical discriminants. An attempt is therefore made here to assess the palaeo-tectonic environments of the Precambrian mafic dykes wide-spread in parts of peninsular India.

\section{Mafic dykes selected and their geological setting}

Seven sets of Precambrian mafic dykes from parts of peninsular India are selected for which the geologic setting is known reasonably well. Though the mafic dykes in some of these areas contain rock types of alkali basalt composition in addition to tholeiitic basalt composition, the former are ommitted as they are not important in assessing the tectonic setting (Pearce and Cann 1973; Floyd and Winchester 1975). The selected seven sets satisfy the sub-alkaline nature of the magma as per the discriminant function of Le Maitre (1968). According to this function, $Z=-0 \cdot 177$ $\mathrm{SiO}_{2}+0.698 \mathrm{TiO}_{2}+0.418 \mathrm{Na}_{2} \mathrm{O}+0.569 \mathrm{~K}_{2} \mathrm{O}$ should have an arithmetic value of less than -2.38 for sub-alkaline rocks. This condition also satisfies the requirement for selecting the analyses for plotting on various diagrams based on chemical discriminants to infer the palaeo-tectonic environment:

The following are the seven sets of mafic dykes selected:

(a) Mafic dykes of Chitaldurg belt, Karnataka (quartz-normative) (Naqvi et al 1972, 1974),

(b) Mafic dykes of Shimoga belt, Karnataka (quartz-normative) (Naqvi et al 1972, 1974),

(c) Newer Dolerite I of Singhbhum belt (Saha et al 1973),

(d) Newer Dolerite II of Singhbhum belt (Saha et al 1973), 
(e) Mafic dykes of Guntur, northeast of Cuddapah basin, A.P. (Ramamohana Rao et al 1984),

(f) Mafic dykes of Ananthapur (Lakshmi Reddy and Murty 1976) and mafic dykes of Chittoor (Chakrapani Naidu and Jayakumar 1980) put together as one set and these are to the west and south of Cuddapah basin, A.P.

(g) Dyke rocks of Cuddapah basin, A.P. (Vemban 1946).

The trace element data for the sets $\mathrm{f}$ and $\mathrm{g}$ are taken from Sankaran (1964), and correspond to the ones given for Tiruthani dykes and Cuddapah dykes respectively. The major elements of these sets have been analyzed by classical gravimetric methods of Groves (1937) (sets c, d, e and g) and by rapid methods of Shapiro and Brannock (1962) (sets a, b and f). The trace element determinations on all the sets have been made on emmission spectrograph (Ahrens and Taylor 1961). Details of precision and accuracy of these analyses given by the above authors suggest a good degree of reliability of the analytical data.

Figure 1 is a sketch map of peninsular India showing the locations of the areas of the mafic dykes studied. Table 1 gives the chemical composition of the mafic dykes. The precise age data on all the mafic dykes are not yet available. The dykes of Chitaldurg and of Shimoga cut across the metavolcanics, metasediments and granites of these belts. The granites of these belts gave $\mathrm{Rb} / \mathrm{Sr}$ age of $2500 \mathrm{Ma}$

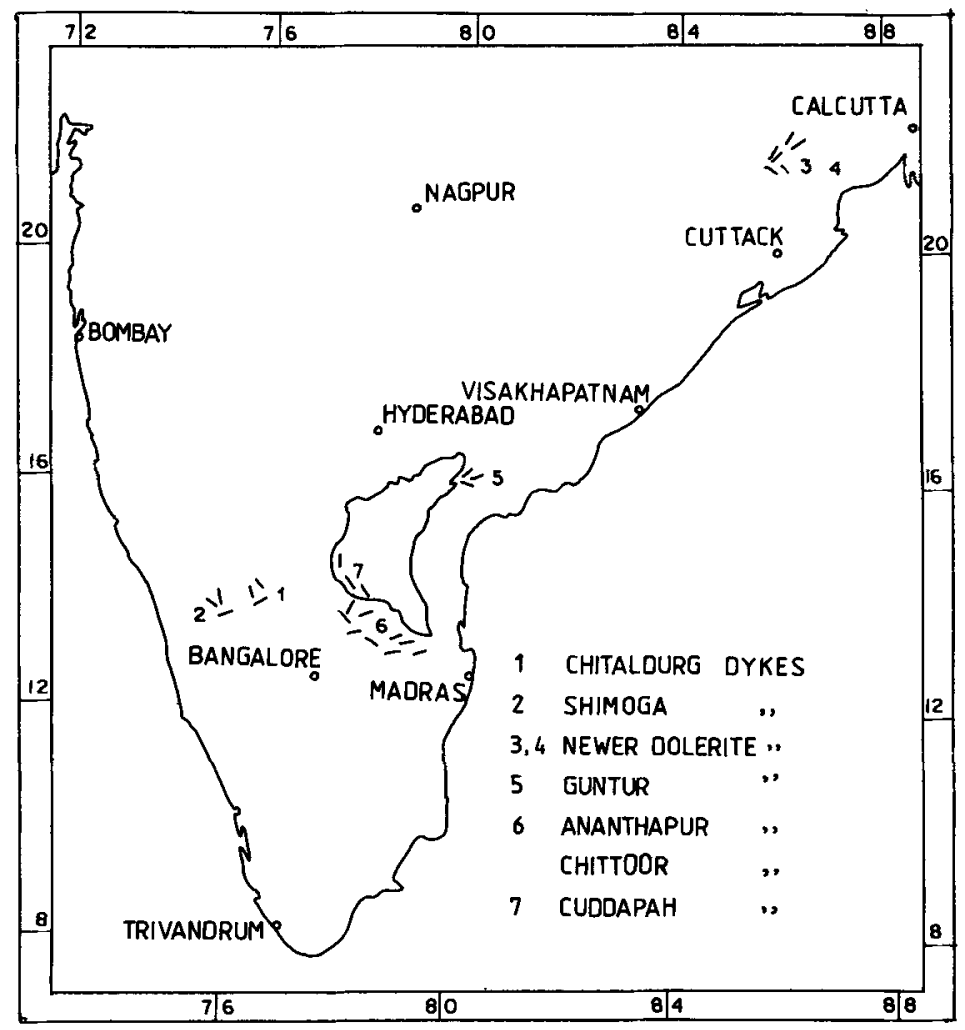

Figure 1. Sketch map showing the locations of the 7 sets of mafic dykes. 
Table 1. Major (\%) and trace (ppm) element composition and calculated chemical parameters of the seven sets of mafic dykes selected.

\begin{tabular}{|c|c|c|c|c|c|c|c|}
\hline & $\begin{array}{c}\text { Chitaldurg } \\
\text { (AV.5) } \\
\text { (1) }\end{array}$ & $\begin{array}{c}\text { Shimoga } \\
\text { (AV.7) } \\
\text { (2) }\end{array}$ & $\begin{array}{c}\text { Newer } \\
\text { Dolerite I } \\
\text { (AV.6) } \\
\text { (3) }\end{array}$ & $\begin{array}{c}\text { Newer } \\
\text { Dolerite II } \\
(\text { AV.9) } \\
(4)\end{array}$ & $\begin{array}{c}\text { Guntur } \\
\text { (AV.8) } \\
\text { (5) }\end{array}$ & $\begin{array}{c}\text { Anantapur- } \\
\text { Chittoor } \\
\text { (AV.6) } \\
\text { (6) }\end{array}$ & $\begin{array}{c}\text { Cuddapah } \\
\text { (AV.7) } \\
\text { (7) }\end{array}$ \\
\hline $\mathrm{SiO}_{2}$ & $52 \cdot 42$ & 53.52 & $51 \cdot 16$ & $51 \cdot 21$ & $51 \cdot 03$ & 48.79 & 48.79 \\
\hline $\mathrm{TiO}_{2}$ & 1.38 & 1.03 & 0.79 & 0.96 & 1.05 & 1.84 & 1.42 \\
\hline $\mathrm{Al}_{2} \mathrm{O}_{3}$ & 14.88 & 14.49 & 12.73 & 14.49 & $14 \cdot 89$ & 14.51 & 14.50 \\
\hline $\mathrm{Fe}_{2} \mathrm{O}_{3}$ & $2 \cdot 85$ & 1.72 & $2 \cdot 15$ & $2 \cdot 43$ & 3.07 & 1.69 & 3.68 \\
\hline $\mathrm{FeO}$ & $8 \cdot 07$ & $9 \cdot 26$ & 8.42 & $9 \cdot 22$ & 8.73 & $10 \cdot 36$ & 9.75 \\
\hline $\mathrm{MnO}$ & 0.02 & 0.06 & $0 \cdot 12$ & 0.19 & 0.23 & $0 \cdot 18$ & 0.41 \\
\hline $\mathrm{MgO}$ & $7 \cdot 06$ & $5 \cdot 74$ & $9 \cdot 26$ & $6 \cdot 22$ & 7.91 & $7 \cdot 31$ & $6 \cdot 38$ \\
\hline $\mathrm{CaO}$ & $7 \cdot 36$ & 8.45 & 8.77 & $9 \cdot 47$ & $9 \cdot 21$ & 11.56 & $9 \cdot 21$ \\
\hline $\mathrm{Na}_{2} \mathrm{O}$ & $3 \cdot 07$ & $2 \cdot 56$ & 2.74 & $2 \cdot 51$ & 1.97 & $2 \cdot 15$ & 2.67 \\
\hline $\mathrm{K}_{2} \mathrm{O}$ & 0.66 & $0 \cdot 84$ & 0.73 & $1 \cdot 00$ & 0.63 & 0.61 & 0.63 \\
\hline $\mathrm{P}_{2} \mathrm{O}_{5}$ & 0.47 & $0 \cdot 17$ & $0 \cdot 30$ & 0.40 & 0.46 & 0.20 & 0.17 \\
\hline $\mathrm{H}_{2} \mathrm{O}^{+}$ & - & - & $3 \cdot 18$ & $2 \cdot 17$ & 0.68 & $0 \cdot 70$ & $2 \cdot 21$ \\
\hline Total: & $98 \cdot 24$ & $97 \cdot 84$ & $100 \cdot 35$ & $100 \cdot 27$ & 99.86 & $100 \cdot 12$ & $99 \cdot 82$ \\
\hline Co & 67 & 46 & 78 & 67 & 42 & 54 & 77 \\
\hline $\mathrm{Cr}$ & 177 & 121 & 858 & 43 & 265 & 57 & 372 \\
\hline $\mathrm{Cu}$ & 59 & 39 & 96 & 164 & - & 105 & 341 \\
\hline Ga & nd & nd & 20 & 23 & 11 & 4 & 4 \\
\hline $\mathrm{Ni}$ & 163 & 93 & 333 & 192 & 122 & 39 & 77 \\
\hline $\mathrm{Sr}$ & nd & nd & 77 & 122 & nd & 287 & 770 \\
\hline Ti & 8273 & 6175 & 4736 & 5755 & 6294 & 11031 & 8513 \\
\hline V & 226 & 215 & 213 & 193 & 350 & 90 & 203 \\
\hline $\mathrm{Y}$ & 18 & 27 & 20 & 20 & 26 & 3 & 3 \\
\hline $\mathrm{Zr}$ & 98 & 109 & 67 & 68 & 64 & $100^{*}$ & $100^{*}$ \\
\hline$Z(-)$ & $6 \cdot 66$ & $7 \cdot 21$ & 6.94 & $7 \cdot 02$ & $7 \cdot 12$ & 6.52 & $6 \cdot 16$ \\
\hline$F_{1}$ & 0.411 & 0.438 & 0.403 & 0.414 & 0.419 & 0.302 & $0 \cdot 347 \underline{1}$ \\
\hline$F_{2}(-)$ & $1 \cdot 504$ & 1.452 & 1.519 & 1.452 & 1.504 & 1.530 & 1.4405 \\
\hline$F_{3}(-)$ & $2 \cdot 387$ & $2 \cdot 337$ & 2.333 & $2 \cdot 324$ & $2 \cdot 342$ & $2 \cdot 369$ & $2 \cdot 2848$ \\
\hline $\mathrm{Ni} / \mathrm{Co}$ & $2 \cdot 43$ & 2.02 & $4 \cdot 26$ & $2 \cdot 88$ & $2 \cdot 90$ & 0.72 & $1 \cdot 00$ \\
\hline $\mathrm{Zr} / \mathrm{Y}$ & $5 \cdot 4$ & 4.03 & $3 \cdot 35$ & $3 \cdot 40$ & $2 \cdot 46$ & $33 \cdot 3$ & $33 \cdot 3$ \\
\hline
\end{tabular}

*Value given for one sample is taken for the group as a whole.

(Crawford 1969). Drury (1984) quotes a model Sm-Nd age of $1700 \mathrm{Ma}$ for the dykes of central Karnataka. The Newer Dolerite I and II are intrusive into Singhbhum granite which gave $\mathrm{Rb} / \mathrm{Sr}$ age of 2950 Ma (Sarkar et al 1979). The Newer Dolerite I and II represent two generations of dyke activity probably spread over from ca $1700 \mathrm{Ma}$ to ca $950 \mathrm{Ma}$ (Saha et al 1973). The dykes of Guntur, Ananthapur-Chittoor cut across the pink granites which are considered older than the Cuddapah sediments. The sills and dykes of the Cuddapah occur as concordant and discordant bodies predominantly within the Vempalle Dolomite Formation. These mafic rocks gave $\mathrm{Rb} / \mathrm{Sr}$ age of $1583 \pm 143 \mathrm{Ma}$ (Crawford and Compston 1973). Some dykes of the Cuddapah cutting across the Vempalle Dolomite Formation and also the Tadepatri Shale Formation gave $\mathrm{Rb} / \mathrm{Sr}$ age of $980 \pm 110 \mathrm{Ma}$ (Crawford and Compston 1973). The above age data on the mafic dykes broadly fall within the Middle Proterozoic. 
The dyke rocks have prominent trends in different regions. The mafic dykes of Chitaldurg and Shimoga have dominant NNW to NW trend with subsidiary NNE and ENE trend. The Newer Dolerite dykes I and II have dominant NNE to NE trend with a subsidiary NW trend. The Guntur, Ananthapur-Chittoor mafic dykes have dominant ENE trend with subsidiary NNE and NW trend. The Cuddapah dykes have NW or basinal N-S trend.

\section{Chemical discriminants applied and the palaeo-tectonic environment of the mafic dykes}

The chemical data of the seven sets of Precambrian mafic dykes presented in table 1 are utilized in the calculation of chemical discriminants. These are plotted in figures 2 to 6 to arrive at the magma type and the related tectonic environment. In all the diagrams, the points plotted and numbered 1 to 7 correspond to the mafic dykes as follows: 1. Chitaldurg, 2. Shimoga, 3. Newer Dolerite I, 4. Newer Dolerite II, 5. Guntur, 6. Ananthapur-Chittoor, 7. Cuddapah.

The $\mathrm{TiO}_{2}-\mathrm{K}_{2} \mathrm{O}-\mathrm{P}_{2} \mathrm{O}_{5}$ diagram (Pearce et al 1975) discriminates the 'primitive' basalts (Jamieson and Clarke 1970, p.183) into ocean floor basalts (OFB) and non-ocean floor basalt (NOFB). All the seven sets plot in the non-ocean floor basalts which correspond to continental basalts.

The functions $F_{1}-F_{2}$ diagram (Pearce 1976) discriminates (figure 2) the basalts of OFB from WPB (which includes OIB) and also those of island arc (CAB + LKT, SHO). Only Ananthapur-Chittoor plots in WPB and the other six plot in

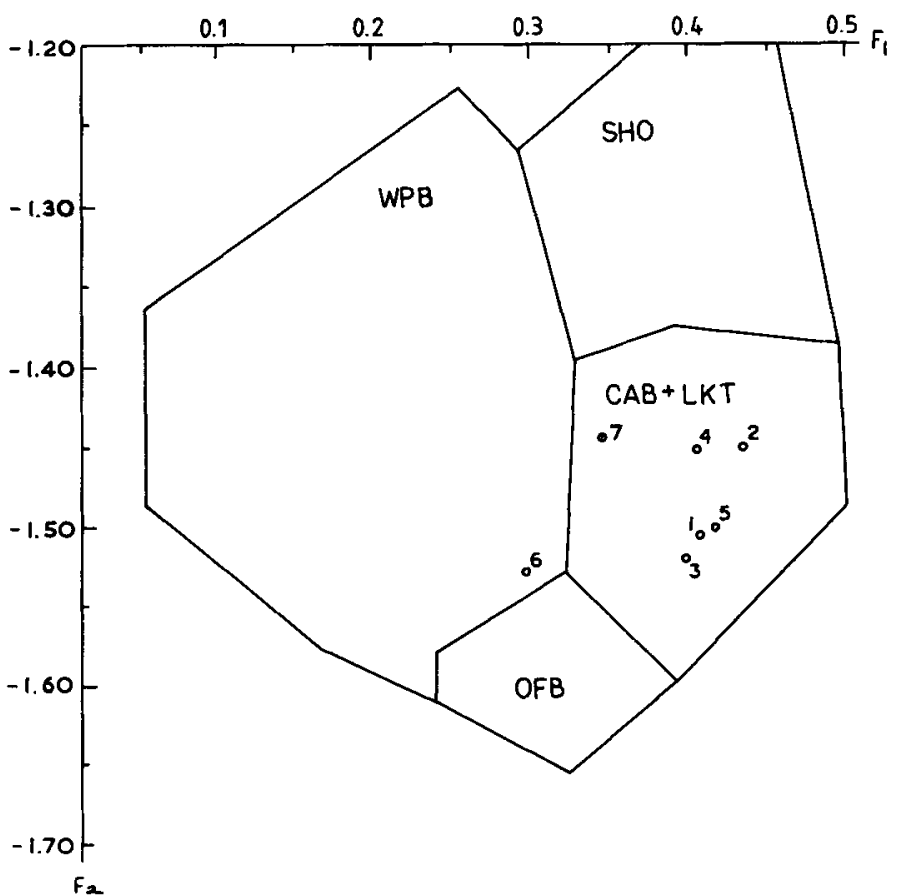

Figure 2. $F_{1}-F_{2}$ diagram (after Pearce 1976). 
$(\mathrm{CAB}+\mathrm{LKT})$ field. The functions $F_{2}-F_{3}$ diagram (Pearce 1976) discriminates CAB from LKT and also SHO of island arc basalts and also those of OFB. The above six sets now plot in LKT. According to Pearce (1976), the basalts which have $F_{1}<0.33$ are WPB. He further proposes, on the basis of study of basalts of SW England and those of Vesuvius, that the basalts which have $F_{1}<0.33$ may be of 'hot-spot' origin and those $>0.33$ may be of island arc origin. The analogy of 'hot-spot' origin to Ananthapur-Chittoor dykes which have $F_{1}<0.33$ is referred to later.

The Ti-Zr-Y, Ti-Zr and Ti-Zr-Sr diagrams (Pearce and Cann 1973) are applicable to fresh and/or altered basaltic rocks, discriminate OFB, CAB, LKT, WPB (which includes OIB) with some overlap in certain region of $\mathrm{Ti}-\mathrm{Zr}$ diagram. In Ti-Zr-Y diagram, Chitaldurg plots in WPB but close to OFB field and Shimoga plots in CAB. Newer Dolerite I and II and Guntur plot in OFB field. Ananthapur-Chittoor and Cuddapah plot outside the fields. In Ti-Zr (figure 3), Chitaldurg plots in OFB. Shimoga plots in CAB. Newer Dolerite I plots in LKT. Newer Dolerite II and Guntur plot in the overlapping region OFB, LKT, CAB. But Ananthapur-Chittoor and Cuddapah plot in OFB. The $\mathrm{Ti}-\mathrm{Zr}$-Sr diagram applicable to fresh rocks, four sets for which $\mathrm{Sr}$ data are available are plotted. Newer dolerite I and II plot in OFB and Ananthapur-Chittoor and Cuddapah plot in LKT. The plots of Ti-Zr-Y, Ti-Zr and Ti-Zr-Sr when read together suggest that Shimoga is CAB, while Chitaldurg is not. Others are LKT or OFB or WPB.

The $\mathrm{MgO} / \mathrm{Al}_{2} \mathrm{O}_{3}-\left(\mathrm{Na}_{2} \mathrm{O}+\mathrm{K}_{2} \mathrm{O}\right) /$ Total $\mathrm{FeO}+\mathrm{TiO}_{2}$ diagram (Green 1973) gives the trend lines of oceanic tholeiite, ocean island basalt (Hawaiian), besides a demarcated field of calc-alkaline rocks (figure 4). Only Chitaldurg plots right on oceanic tholeiitic trend. Newer Dolerite I plots towards the oceanic tholeiite side. Shimoga, Newer Dolerite II, Ananthapur-Chittoor, Guntur and Cuddapah plot on a line in between the oceanic tholeiite trend and the ocean island (Hawaiian) trend. Among these Shimoga plots closer to the demarcated field of calc-alkaline rocks.

The $\mathrm{FeO}^{*}$ (Total)- $\mathrm{MgO}-\mathrm{Al}_{2} \mathrm{O}_{3}$ diagram (Pearce et al 1977) discriminates (figure 5) effectively subalkaline basalts into OFB, OIB, CONB and orogenic (equated to Island Arc: $O R N B=I A B$ ) basalts. In this diagram OIB field represents Hawaiian type of basalts occurring on the oceanic crust of WPB and CONB (continental) basalts represent rift type basalts of WPB (Pearce et al 1977). In figure 5,

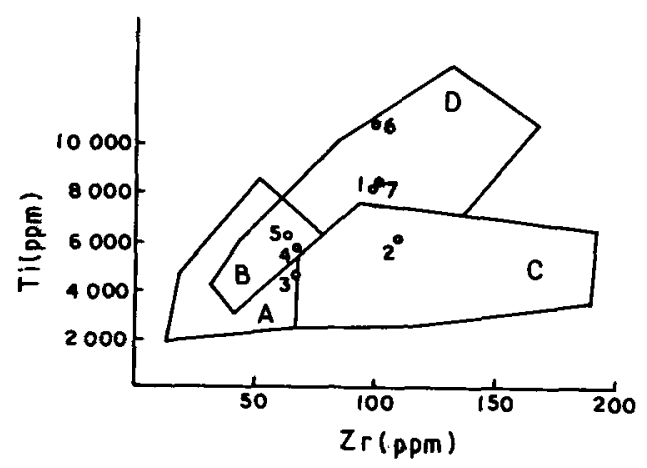

Figure 3. Ti-Zr diagram (after Pearce and Cann 1973). A and B-LKT C and B-CAB. $\mathrm{D}$ and $\mathrm{B}-\mathrm{OFB}$. 


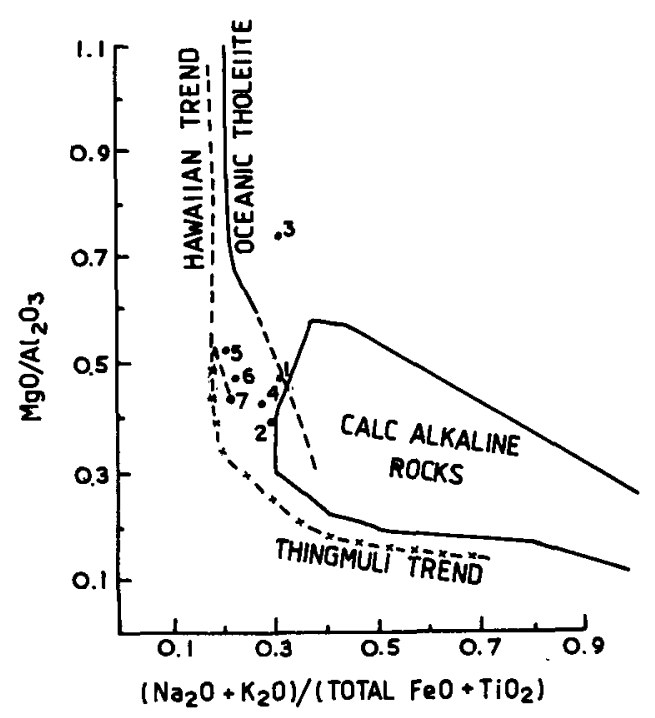

Figure 4. $\mathrm{MgO} / \mathrm{Al}_{2} \mathrm{O}_{3}-\left(\mathrm{Na}_{2} \mathrm{O}+\mathrm{K}_{2} \mathrm{O}\right) /\left(\mathrm{Total} \mathrm{FeO}+\mathrm{TiO}_{2}\right)$ diagram (after Green 1973).

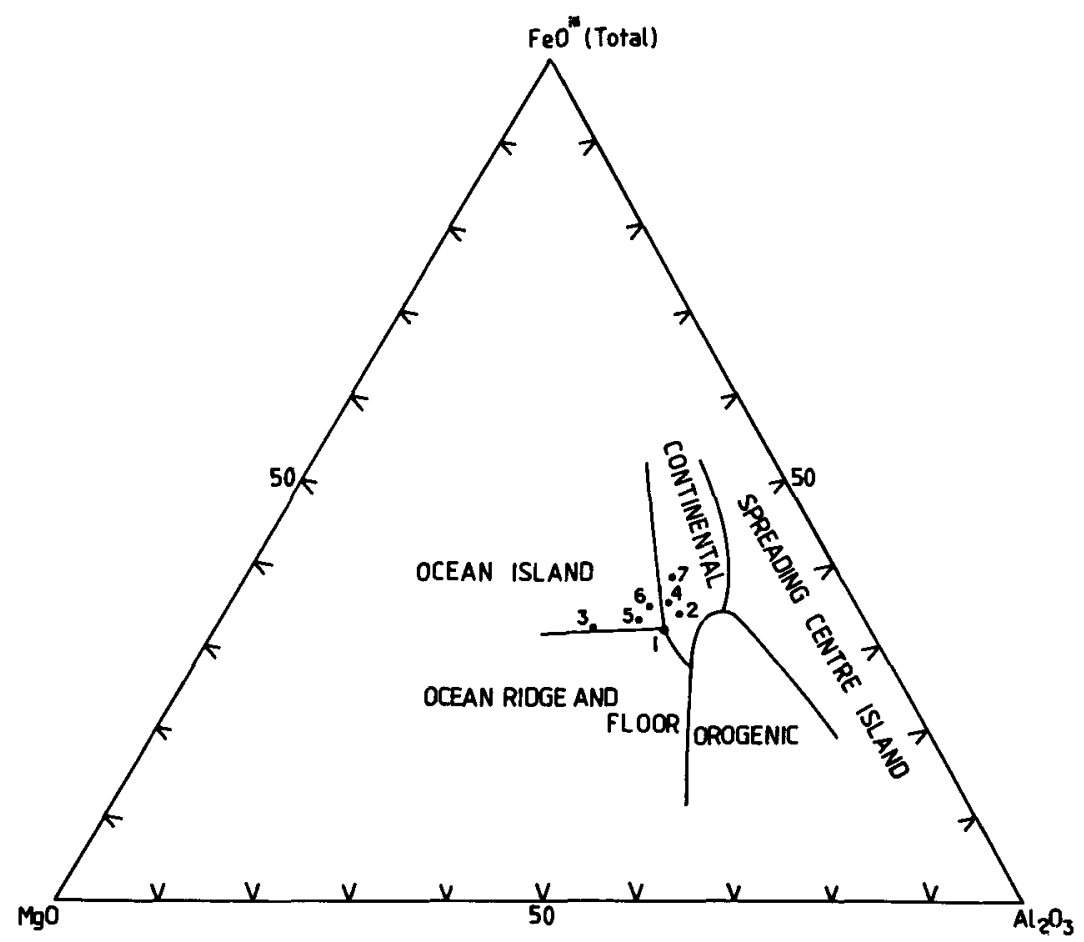

Figure 5. $\mathrm{FeO}^{*}$ (Total)- $\mathrm{MgO}-\mathrm{Al}_{2} \mathrm{O}_{3}$ diagram (after Pearce et al 1977). 
Chitaldurg plots at the tri-junction of OFB, OIB and CONB, but Shimoga plots in OIB. Newer Dolerite I plots on the border line of OFB and OIB and Newer Dolerite II plots in CONB. Guntur and Anantapur-Chittoor plot in OIB while Cuddapah plots in CONB. None of the sets plot in the orogenic field, and according to the authors it effectively discriminated only $55 \%$ of the data they used. This discriminant diagram brings out effectively the difference in the tectonic settings of Chitaldurg from Shimoga, Newer Dolerite I from Newer Dolerite II and to a good extent the Guntur, Ananthapur-Chittoor from Cuddapah.

The New Ti- $\mathrm{Zr}$ diagram (figure 6) (Pearce 1982) gives the fields of the tectonic environment for the basalt in terms of MORB, Arc (IAT) and WPB with some overlap. In figure 6, Chitaldurg plots in MORB but Shimoga plots in Arc (= IAT); Newer Dolerite I plots in MORB but Newer Dolerite II plots in Arc/MORB; Guntur also plots in Arc/MORB; but Ananthapur-Chittoor and Cuddapah plot in WPB/MORB.

\section{Interpretation of the Palaeo-tectonic environment}

The magma types obtained from the application of chemical discriminants and their plottings in figures 2 to 6 suggest the following tectonic environments for the seven sets of mafic dykes.

The Chitaldurg set of dykes does plot variously and characteristically it plots at the tri-junction of OFB, OIB and CONB in figure 5 and in OFB in figure 6. The high $\mathrm{Cr}$ and $\mathrm{Ni}$ and $\mathrm{Co}$ with a $\mathrm{Ni} / \mathrm{Co}$ ratio of $2 \cdot 4$ (table 1 ) is suggestive of ocean floor basalt affinity (Condie 1976). It does plot on the trend of oceanic tholeiite in figure 4. Naqvi et al $(1972,1974)$, based on field and other studies assumed that the Chitaldurg dykes are derived from a single magmatic source beneath them while Shimoga dykes are not. The high $\mathrm{Cr}$ also supports MORB affinity. But the high $\mathrm{Zr}$ combined with low $\mathrm{Y}$ giving $\mathrm{Zr} / \mathrm{Y}$ of 5.4 for Chitaldurg dykes suggest a continental basalt affinity (Wood et al 1979). In view of the overall OFB affinity of Chitaldurg

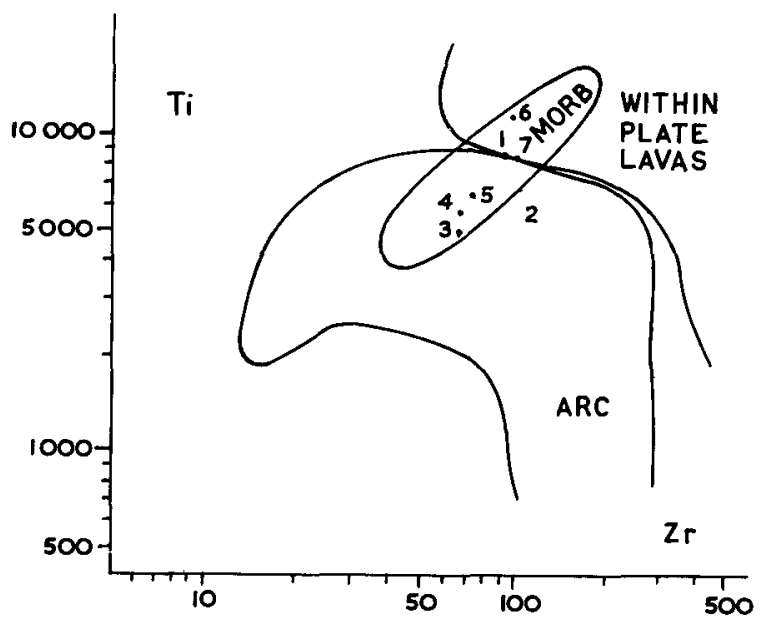

Figure 6. Ti- $\mathrm{Zr}$ diagram (after Pearce 1982). 
dykes, it is suggested that these represent an attempt to rift and to generate oceanic crust in the southern peninsular India.

The Shimoga set of dykes shows a consistent affinity to CAB (which is related to Island Arc equated to orogenic basalts) (figures 2, 3, 4 and 6 and on Ti-Zr-Y diagram). Also, the high $\mathrm{Co}$ in relation to $\mathrm{Ni}$ (table 1) is characteristic of island arc basalts (Condie 1976) to which CAB is related. In view of this affinity it is suggested that the Shimoga dykes represent orogenic intrusive environment following the phase of folding.

Newer Dolerite I and II which differ petrologically (Saha et al 1973) show up their differences in magma types. Newer Dolerite I shows affinity to OFB (figures 5 and 6 and on $\mathrm{Ti} / 100-\mathrm{Zr}-\mathrm{Sr} / 2$ diagram). Further its high $\mathrm{Cr}$ and high $\mathrm{Ni} / \mathrm{Co}$ (table 1 ) is suggestive of OFB. The Newer Dolerite II shows affinity to CONB (figure 5) or $\mathrm{CAB}$ (figure 4). These differences combined with the postulated period of instrusions from $1700 \mathrm{Ma}$ to $1000 \mathrm{Ma}$ (Saha et al 1973) suggest that Newer Dolerite I represents an attempt to rift and to generate oceanic crust at the beginning of Middle Proterozoic and that Newer Dolerite II represents healing and filling of the fractured crust by the end of Middle Proterozoic in the Singhbhum region.

The Guntur and Ananthapur-Chittoor dykes have similarities wherein both show dominant OIB character (figure 5) and the latter has a clear tendency to WPB (figures 2,6 ). These characters combined with low Ni/Co and $F_{1}$ value less than 0.33 for Ananthapur-Chittoor dykes strongly suggest a 'hot-spot' environment for these dykes. These occur profusely at the Cuddapah-Archaean boundary (figure 1). Burke and Dewey (1973) proposed a 'hot-spot' in the area of Guntur and intraplate seismicity in the areas is confirmed (Chandra 1977). The idea of Drury and Holt (1980) and Drury (1984) of lithospheric doming due to thermal event before the initiation of Cuddapah Basin fits well into the presently suggested 'hot-spot' environment with intraplate ocean island basalt affinity of the dykes of Ananthapur-Chittoor and also those of Guntur.

The Cuddapah dykes have transitional characters of OFB (MORB) (figures 3, 6), LKT/CAB (figure 2) and CONB (figure 5). Their low Ni/Co negates purely OFB character. The transitional nature of the magma type suggests that the Cuddapah dykes may represent compound events of rifting and of healing of the fractured continental crust.

\section{Conclusions}

The mafic dykes widespread in parts of peninsular India covering a period from $1700 \mathrm{Ma}$ to $980 \mathrm{Ma}$ give important clues to the nature of thermal events of the mantle during the whole of Middle Proterozoic. The results show that Chitaldurg and Newer Dolerite I have OFB affinity, Shimoga CAB, Guntur, AnanthapurChittoor OIB, Newer Dolerite II CONB and Cuddapah transitional to all types. An attempt to rift by Chitaldurg and Newer Dolerite I are inferred. A 'hot-spot' activity leading to lithospheric doming by Guntur, Ananthapur-Chittoor dykes is proposed. Shimoga dykes are orogenic while Newer Dolerite II is fracture filling type. The Cuddapah dykes represent a compound event of rifting and healing the fractured continental crust. 


\section{Acknowledgements}

BVSNR and MVRR are thankful to CSIR for financial assistance.

\section{References}

Ahrens L H and Taylor S R 1961 Spectrochemical analysis (London: Addison Wesley) II ed. Allégre C J 1982 Tectonóphysics 81109

Allégre C J, Brevart O, Dupré B and Minster J F 1980 Philos. Trans. R. Soc. London A297 447

Burke K and Dewey J F 1973 J. Geol. 31406

Chakrapani Naidu M G and Jayakumar D 1979 Indian Mineral. 206

Chandra U 1977 Bull. Seismol. Soc. Am. 671387

Condie K C 1976 Plate tectonics and crustal evolution (New York: Pergamon Press)

Crawford A R 1969 J. Geol. Soc. India 10117

Crawford A R and Compston W 1973 J. Geol. Soc. Aust. 19453

Drury S A $1984 \mathrm{~J}$. Geol. Soc. India 25437

Drury S A and Holt R W 1980 Tectonophysics 651

Dupré B, Lambret B, Rousseau D and Allégre C J 1981 Nature (London) 294552

Floyd P A and Winchester J A 1975 Earth Planet. Sci. Lett. 27211

Gill J B 1984 Earth Planet Sci. Lett. 68443

Green N L 1973 Can. Mineral. 12144

Groves A W 1937 Silicate analysis (London: Thomas Murby)

Hamelin B, Dupré B and Allégre C J 1986 Earth Planet Sci. Lett. 76288

Hanson G N $1977 \mathrm{~J}$. Geol. Soc. London 134235

Hawkesworth C J, O'Nions R K, Pankhurst R J, Hamilton P J and Evensen N M 1977 Earth Planet. Sci. Lett. 36253

Jamieson B G and Clarke D B $1970 \mathrm{~J}$. Petrol. 11183

Lakshmi Reddy G and Murthy M S 1976 J. Indian Acad. Geosci. 1927

Langmuir C H, Bender J F, Bence A E, Hanson G N and Taylor S R 1977 Earth Planet. Sci. Lett. 36133

Langmuir C H and Hanson. G N 1980 Philos. Trans. R. Soc. London Ser. A297 383

Le Maitre R W 1968 J. Petrol. 9220

Morris J D and Hart S R 1983 Geochim. Cosmochim. Acta 472015

Naqvi S M, Divakara Rao V, Satyanarayana'K and Hussain S M 1972 Geophys. Res. Bull. 10109

Naqvi S M, Divakara Rao V, Satyanarayana K and Hussain S M 1974 Geol. Mag. 111229

O'Nions R K, Evensen N M, Hamilton P J and Carter S R 1978 Philos. Trans. R. Soc. London A258 547

O'Nions R K, Evensen N M and Hamilton P J 1979 J. Geophys. Res. 86091

O'Nions R K and Hamilton 1981 Philos. Trans. R. Soc. London A301 473

Pearce J A 1976 J. Petrol. 1715

Pearce J A 1982 in Andesites (ed) R S Thorpe (Chichester: John Wiley) 525

Pearce J A and Cann J R 1973 Earth Planet. Sci. Lett. 19290

Pearce J A and Norry M J 1979 Contrib Mineral. Petrol. 69 33

Pearce T H, Gorman B E and Birkett T C 1975 Earth Planet. Sci. Lett. 24419

Pearce T H, Gorman B E and Birkett T C 1977 Earth Planet. Sci. Lett. 36121

Ramamohana Rao T, Satyanarayana Raju B V and Madhysudhana Rao G S 1984 J. Indian Acad. Geosci. 2723

Saha A K, Sankaran A V and Bhattaracharyya T K 1973 J. Geol. Soc. India 14329

Sarkar S N, Saha A K, Boelrijk N A I M and Hebeda E H 1979 Indian J. Earth Sci. 632

Sankaran A V $1964 \mathrm{~J}$. Indian Geosci. Assoc. IV 97

Shapiro L and Brannock W W 1962 USGS Bull. 1144-A 1

Stern R J 1982 Geol. Soc. Am. Bull. 93477

Sun S S 1980 Philos. Trans. R. Soc. London A297 409

Tarney J, Wood D A, Saunders A D, Cann J R and Varet J 1980 Philos. Trans. R. Soc. London Ser.A 297179

Thompson R N, Morrison M, Ann Mattey D P, Dielin A P and Morbath S 1980 Earth Planet. Sci. Lett. 501 
Vemban N A 1946 Proc. Indian Acad. Sci. A23 347

Wilkinson J F G 1985 Earth Planet. Sci. Lett. 75129

Wood D A, Joron J L and Trevil M 1979 Earth Planet. Sci. Lett. 45326

Wood D A 1980 Earth Planet. Sci. Lett. 5011 